\title{
Perspective of nursing students about active learning and insertion in the job market
}

\author{
Visão do estudante de enfermagem sobre aprendizagem ativa e sua inserção no mercado de trabalho \\ Visión del estudiante de enfermería sobre aprendizaje activo y su inserción en el mercado laboral
}

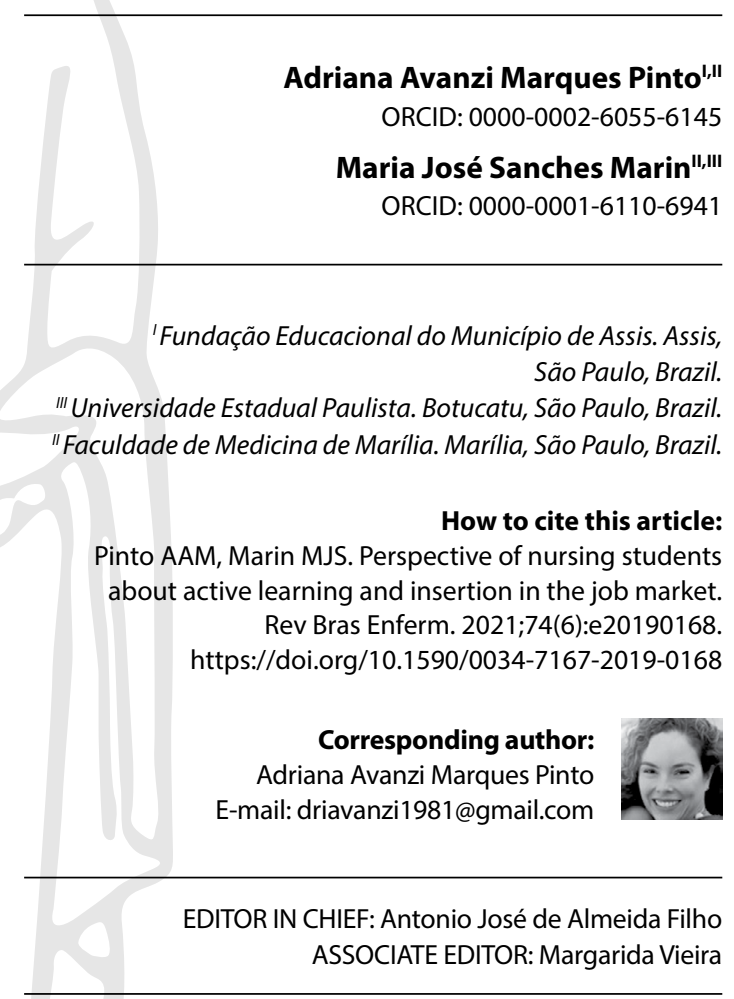

Submission: 03-07-2019

\begin{abstract}
Objective: to understand the perception of alumni from a nursing course which uses active learning methods about their insertion in the job market. Methods: descriptive and exploratory study with a qualitative approach, carried out through 17 interviews with alumni from 2012 and 2014. The analysis took place using Dialectic Hermeneutics, as subsidized by the theoretical framework of the Theory of Complexity. Results: the statements of the alumni showed aspects related to safety to act in the job market, to stimulating proactivity and initiative for learning as proposed by the active method, to difficulties in teamwork, and to the lack of experience in certain specialized fields. Final Considerations: there are advances and challenges marked by contradictions in the way the alumni act and think as they enter the job market, which is an inherent condition to processes of change, from the perspective of complex thinking. Descriptors: Education, Nursing; Outcome Assessment; Students, Nursing; Problem-Based Learning; Job Market.
\end{abstract}

\section{RESUMO}

Objetivo: compreender a percepção sobre a inserção no mercado de trabalho dos egressos de um curso de Enfermagem que utiliza métodos ativos de aprendizagem. Método: estudo exploratório e descritivo, com abordagem qualitativa, realizado a partir de 17 entrevistas com egressos dos anos de 2012 a 2014. A análise se deu por meio da técnica da Hermenêutica Dialética, subsidiada pelo quadro teórico da Teoria da Complexidade. Resultados: identificouse, na fala dos egressos, aspectos relacionados à segurança para atuação no mercado de trabalho, ao estímulo à proatividade e à iniciativa para o aprendizado proporcionado pelo método ativo, à dificuldade para o trabalho em equipe eà falta de vivência nas especialidades. Considerações Finais: revelam-se avanços e desafios marcados por contradições na forma de agir e pensar do egresso ao se inserir no mercado de trabalho, o que representa uma condição inerente aos processos de mudanças, perspectiva do pensamento complexo. Descritores: Educação em Enfermagem; Avaliação de Resultados; Estudantes de Enfermagem; Aprendizagem Baseada em Problemas; Mercado de Trabalho.

\section{RESUMEN}

Objetivo: comprender la percepción sobre inserción en mercado laboral de egresos de un curso de Enfermería que utiliza métodos activos de aprendizaje. Método: estudio exploratorio y descriptivo, con abordaje cualitativo, realizado por 17 entrevistas con egresos de los años de 2012 a 2014. El análisis ocurrió por medio de técnica de la Hermenéutica Dialéctica, subsidiada por cuadro teórico de la Teoría de la Complejidad. Resultados: identificó, en declaración de egresos, aspectos relacionados a la seguridad para actuación en mercado laboral, al estímulo a la proactividad e iniciativa para el aprendizaje proporcionado por método activo, a la dificultad para el trabajo en equipo y a la falta de vivencia en las especialidades. Consideraciones Finales: revelan avanzos y desafíos marcados por contradicciones en la manera de actuar y pensar de egreso al inserirse en el mercado laboral, lo que representa una condición inherente a los procesos de cambios, perspectiva del pensamiento complejo. Descriptores: Educación en Enfermería; Evaluación de Resultados; Estudiantes de Enfermería; Aprendizaje Basado en Problemas; Mercado Laboral. 


\section{INTRODUCTION}

Considering current cultural, political, and scientific transformations, health education must be analyzed based on the policies that are proposed, so improvements regarding care fragmentation and the disarticulation of the health care network can be achieved. In this context, a model of attention has been advocated which involves developing integral, universal, and equal care. To do so, the education also must go through changes that aim to stand by these principles.

This movement is in accordance to the Law of Directives and Bases for Education (LDB), which increases the flexibility of curricular organization. With the National Curricular Guidelines (NCG) for health courses, the role of the education of the professionals was defined, for them to be reflective, learn how to act according with their local reality, and promote changes in the health determinants ${ }^{(1-3)}$.

The National Curricular Guidelines for nursing courses (DCN-Enf) advocate that the professional should be educated to act in the different fields and knowledge of nursing, in a generalist, critical, reflective, ethical, and socially-responsible way. Therefore, this professional will be able to act with regard to the health-disease problems of the population and their determinants, while emphasizing education and health promotion actions integrally ${ }^{(1-2)}$.

After nearly two decades defining the DCN-Enf, advances can be noticed towards the profile desired. Among them, are: the recognition of the multidimensionality of the professional practice in overcoming a (fragmented and simplified) way to think about reality; a stronger association between biological and social health care bases; an integration between theory and practice, as well as a teaching-research-extension group; diversifying the settings of practice by adopting active learning methods; and collective construction ${ }^{(1)}$.

Many challenges are still overarching, since the necessary changes involve new ways of teaching and caring. Therefore, these changes are paradigmatic, demanding the incorporation of the concepts to those that already underlie the perspective of professionals graduated in the traditional model of teaching and fragmented care. Therefore, it can also be added that directives, in themselves, do not provide the necessary conditions for the actualization of a process of change. Furthermore, they have not provided sufficient specificity and objectivity for their implementation $^{(1,3)}$. Considering that, the Brazilian Nursing Association ( $A B E n$ ) headed a movement that was widely discussed in the National Seminary for Nursing Directives (SENADEN), carried out in Curitiba to advance this formation ${ }^{(1,4)}$.

It stands out that, even with the predicted changes, the guidance incorporated must, necessarily, be based on the current social context, and, more specifically, in the national policy of health. This fact considers that forming health professionals to attend to social demands is an activity that gains its own peculiarities as one understands how impossible it is to disassociate theory and practice and understands that an integral view of men and the broadening of the concept of "care" are essential to the work process ${ }^{(1,4)}$.

As a result, one is compelled towards education by competence and towards the use of active learning methods. The term "competence as applied to work" is defined as a set of knowledge, abilities, and attitudes needed to develop the functions of the workers, to reach the goals of the institution. In education, the term is also presented as the ability to articulate values, abilities, and knowledge, allowing the individual to face the difficulty, mobilizing previous knowledge, and adapting it to the resolution of the situation that must be confronted. Elaborating this concept involves different types of knowledge, such as knowing to be, knowing to know, and knowing to do, actions that are articulated in the development of a task or activity ${ }^{(1,5-6)}$.

This understanding requires a more profound engagement with the professional practice, leading to the use of active learning methods. In them, knowledge is built through practical experiences, providing an early contact with the fields of action and the users of the health services. Students start to be the protagonists of the construction of their own knowledge, based on their own experiences, which involves the acquisition of abilities and competences that go beyond the technical-scientific domain, since they must be capable of creating, planning, implementing, and evaluating policies and actions in health for the population, in addition to solving routine problems of the health services ${ }^{(1,7-12)}$.

The trajectory of constructing and reconstructing new learning and care models in health relates to the Complexity Theory, which is presented as a critic to the reductionist process of teaching, especially in health sciences, since the curricular organization of the disciplines fragments human beings who seek to meet their functioning.

The Complexity Theory seeks to understand how the whole is in the parts, and how the parts are present in the whole. It emphasizes the need of a process to understand the world which starts with education, encouraging autonomy and criticism about what is experienced and sought, bringing education and hope to a consequent social transformation ${ }^{(1,13-17)}$. Furthermore, it criticizes the curricular organization by disciplines, since it is not conducive to connecting different fields, thus presenting gaps that make learning more difficult.

As a result, one can ascertain that the current social context imposes, to the higher education institutions (HEI) in the field of health, the need to reformulate the way in which they teach. As a starting point, the National Health Policy must be applied over a world characterized by diversity, globalization, and the growing advance of knowledge ${ }^{(1)}$. Considering the complexity represented by the necessary changes, which are permeated by advances and challenges, this study starts with the following question: How are the alumni of a nursing course which, since 2003, has implemented an integrated curriculum, guided by competence and using active learning methods, being inserted in the job market?

\section{OBJECTIVES}

To understand the perception of alumni from a nursing course which uses active learning methods about their insertion in the job market.

\section{METHODS}

\section{Ethical aspects}

The Research Ethics Committee of the proponent and coparticipant institutions, respectively, approved this study. To 
maintain anonymity, the institution was referred to as $\mathrm{HEl}$, and the letters "EG", followed by a number 1, 2, 3... 32, were used to denote the nursing alumni, guaranteeing secrecy and data confidentiality.

\section{Type of study}

Qualitative field study, based on Dialectic Hermeneutics and on content analysis, carried out from semistructured interviews with nursing alumni from a HEl in inland São Paulo State.

\section{Methodological procedures}

\section{Study Setting}

The HEl evaluated in the study currently counts on two graduation courses (Nursing and Medicine), in addition to a hospital complex with two units and one ambulatory network with different specializations, being the reference service for 64 cities in the region.

The nursing course of this college changed in its politicalpedagogical project from 1998 on, since, at that moment, the entire territory of the country already discussed the need for changes, in accordance to the principles and directives of SUS. To do so, this work sought to understand the curriculum from an integrated perspective, that favored the articulations of theorypractice and work-teaching ${ }^{(1,18)}$.

The pedagogical concepts adopted were based on the criticalreflexive concept of education, which sees the student as an active and participant subject in their own learning-teaching process ${ }^{(19)}$. In the curricular base proposed in 1998, the disciplines were no longer offered separately, and started to form educational units, whose content was developed in an integral way, followed by activities that were contextualized with the practice reality experienced by the students ${ }^{(20)}$, leading them to achieve significant learning ${ }^{(1)}$.

This curriculum model went through constant evaluations from all those involved in the teaching learning process (professors, students, managers, health service professionals that work in partnership); and, in 2003, a new reformulation was implemented ${ }^{(1,20)}$.

Its current structure includes the Professional Practice Unit (UPP) and the Systematized Educational Unit (UES), aimed at promoting the development of cognitive, affective, and psychomotor resources that can be mobilized and integrated to carry out tasks. Therefore, the objective is to identify the health needs of the individual, the family, and the collective, as well as to elaborate the care plan, aiming to implement it.

The UES follows the Problem-Based Learning (PBL) methodology, which makes it possible to recover and elaborate cognitive processes related to the problem situations presented in the different learning settings. In actual settings (UPP), the health needs of the person/family are put into question, the health problem is formulated, and the plan of care is elaborated ${ }^{(1,20)}$.

From the 2nd year on, an elective internship is carried out, allowing the curriculum to be flexible, since the student can choose the location they prefer. It stands out that, for this model of curriculum, it was necessary to establish a close partnership with the Primary Care of the city. The students are separated in groups of $12-4$ nursing students and 8 medicine students - in Family Health Strategy (ESF) units, in which they remain until the end of the 2 nd year. The aim is to establish a bond with the families they accompany and with the health team. In the 3rd year and in a semester from the 4th year, the activities are carried out in a hospital setting. In the 4 th year, they go back to the ESF to go through a supervised internship for one semester ${ }^{(1,20)}$.

\section{Sample, collection and organization of data}

The population of the study included 86 nursing alumni from a state HEl inland in the São Paulo State, formed from 2012 to 2014. To contact these participants, a list including the alumni from the period mentioned was procured from the $\mathrm{HEI}$, and then, they were sought after using the technological resources available (Google, Facebook). After getting in touch with one member from a specific class, the data (telephone number or email) of the alumni who were part of the sample of the study were required, and they were invited to participate in the research. The 68 alumni were contacted, and 17 answered, accepting to participate in the study ${ }^{(1)}$.

Data collection took place from May 2015 to January 2017, through semistructured interviews, which lasted for a mean of 30 minutes. For these interviews, a script for data collection to identify the alumni was elaborated, including marital state, city where they live/work, age, children, further professional education, professional data, place of work, income, time working in the nursing field, time they took to enter in the job market, work activity, difficulties and facilities in working as a nurse, and what could change in their formation to make entering the job market easier $^{(1)}$.

The interviews were carried out according to the availability of the participants (in person, via Skype or telephone, using the speaker mode, which allows for recording). For long-distance interviews, the free and informed consent form was sent via email and sent back by the participant after being signed and scanned. In all cases, a private location was selected, and the interview only started after all legal needs were attended, that is, after the signed consent form was delivered by the participant ${ }^{(1)}$.

\section{Data analysis}

Data analysis took place using Dialectic Hermeneutics, as subsidized by the theoretical framework of the Complexity Theory, as proposed by Morin (1990)(16). In this theory, seven principles stand out, which favor the understanding of the changes taking place in the field of teaching and health care. These are: 1) the Systemic Organizational one - which seeks to connect the knowledge of the parts to the whole; 2 ) the Holographic - adds that not only the parts are in the whole, but the whole is in the parts; 3 ) the Retroactive - allows for an understanding of selfregulating processes, breaking linear causality; 4) the Recursive Circuit - indicates that the products and effects are producers and causes of what they generate; 5) the Autonomy - indicates that both autonomy and dependency are tightly connected; 6) the Dialogic - reinforces the importance of not excluding contradictory 
notions to understand a phenomenon; and 7) the Reintroduction of Knowledge - which arises from the understanding that knowledge stems from the interpretation of a being inserted in a certain reality at a certain time $\mathrm{e}^{(1,15-17)}$.

The use of the analysis technique using Dialectic Hermeneutics in human and social sciences started at the highest point of the first criticism made about positivist methodology, as it became understood that it is impossible to separate the subject from the object, or the whole from the parts, since what ones seek to explain are the meanings, not the causes of a phenomenon ${ }^{(21)}$.

The epistemology of this type of analysis, in qualitative research, starts with understanding that the context in which the subject lives and their culture interfere in human communication, with an unprejudiced interpretation from the observer. This interaction between subject and object is defined as "language"(1,21-23).

This technique highlights the search for differences and similarities between the context of the investigator and that of the investigated; the exploration of author definitions; the sharing of the worlds of investigator and investigated; the understanding of the data observed, supported by a reflection based on the historical context, judgment, and decision about the facts; and the production of a report in which all views can be contemplated ${ }^{(1,21-23)}$.

This way to analyze is characterized by two stages of interpretation: the grammatical stage, in which the discourse is analyzed through the words and concepts presented; and the psychological stage, in which the meaning of these words for the people who spoke them is interpreted. These two moments put in evidence the hermeneutic view of the analysis, which seeks a relation between thought and language. In the dialectic, there is a dialog between opposites, and the facts, the language, the symbols and the culture are explored to find a contradiction and perform a critical analysis of them ${ }^{(1,21-23)}$.

As a result, by articulating Hermeneutics and Dialectics, one finds a path to base the analysis in qualitative researches, valuing the complementarity and the divergence in relations expressed through language. With the premise that there is no unbiased investigator, Hermeneutics gives voice to the consensus, the mediation, and the accord; Dialectics guides towards difference and criticism. Both complement each other and illuminate the data observed and studied, showing their identity through opposition and highlighting it through reflection ${ }^{(1,21-23)}$.

\section{RESULTS}

With regard to the characterization of the participants of the research, there were 17 alumni (all women). Most live inland São Paulo State, are from 23 to 27 years old, single, with no children, and finished a specialization or are undergoing a post-graduation. Concerning their professional actions as nurses, five have worked as nurses, six as interns, and one as a professor, while four never worked in the field of nursing. Most of them have been working in the field for more than a year. Regarding their income, it varied from 1.06 to 6.4 minimum wages, which, in 2017, was worth R\$ 937.00. Most participants are in the 3.06 minimum wages range.

Based on the analysis of the interviews, four themes were selected, as described below.

\section{Security resulting from constant proximity to practice}

In the statements of the alumni, it is possible to note that they feel secure to face their professional activities, which they attribute to their insertion in the professional practices since the first years of the course, which end in the 4th ano, when they have a supervised internship.

Ah [...] I liked it, you know? I think I could find myself [...] feeling secure and I liked that, because its autonomy. I felt secure [...]. (EG9)

Ithink [name of the institution] stands out with regard to the contact you have [with practice] since the first years [...]. (EG1)

When I had to work for real, it was not so alien, you know? I knew a lot because of the internships and experiences... so it wasn't that hard. (E14)

[...] [name of the institution], in the 4th year, they put us to do the nurses' [work] in the hospital sector, right? And the same goes for collective health. (EG13)

\section{Education targeted at proactivity, initiative, and signifi- cant learning}

It is possible to understand that the alumni were encouraged to have initiative and autonomy to learn to carry out activities from their daily work lives by themselves.

I think the graduation helped a lot in this part, helped us being more active. Not being so much in the classroom. (N2)

Because the method teaches you to go for it, to seek what you are missing [...] I think we brought that into our lives. (EG2)

Oh [...] / think it was the practice. Because I noticed that the workers tested us a lot, so, since I always had initiative, which I learned to have at the course [...]. (EG3)

I believe that, because it was an active methodology, I learned to have autonomy and always go for it. (EG12)

Because we always studied by ourselves [...] there were many professors offering support if you had questions, but they explained a lot how to study by yourself. (EG14)

[...] the things you really keep, which you really [value], are the really significant learning we talk about. (EG5)

You have initiative, proactivity is demanded for your graduation. You are proactive, because they demand it during graduation. (EG8)

\section{Difficulties to develop teamwork}

The alumni also pointed at difficulties to face situations in their work context, which is inherent to complex works of paradigm change. As a result, although there is a base which encourages seeking reflection and dialog to aggregate knowledge to practical situations, the daily work is developed in a mechanical way. Therefore, one can notice that the changes take place in a dialogic movement, marked by contradiction. 
And the difficulty I had was being able to find my space as a nurse and show my perceptions, my [...] my knowledge [...] and to bring the discussion up in a way it would be accepted, discussed and taking seriously [...]. (EG9).

[...] I think that, in graduation, we have a false hope that we can have an articulation with the physicians. Because you don't sit to discuss with the physician [...] you don't sit to discuss with the psychologist [...] you often don't even know who the psychologist of the ward is, although you're there working, you don't know during graduation [...]. (EG9)

It was a bit difficult, the acceptance [...] because they found I had just graduated [...] but I [...] I adapted well after that, you know? [...] Because I noticed the workers tested us a lot. (EG3)

\section{Lack of experience in some fields and specialties during graduation}

During the interviews with the alumni, it was also possible to find that they felt they lacked practical training in specific fields, considering that, often, after graduated, they find work in these places.

[...] in nursing, we don't go through psychiatry [...] So, when I started my extra training, it was a sea of discoveries [...] because I didn't know absolutely anything. (EG9)

[...] in college we don't cover this service, which I think it's a pity. I always have. Because it's where we learn the most, in the ICU and in the emergency room, and these two [...] these two subjects are not mandatory there, I was the one to go after it. (EG3)

In management, maybe there is a difficulty because the places themselves make this separation, between the assistance nurse and the manager nurse [...] So, when we are in this setting, we end up in the assistance part, with the activities of this nurse, and have little contact with management. (EG12)

\section{DISCUSSION}

Feeling secure to carry out a task is closely related to the learning that is both the base and the guideline to carry out what was previously experienced. In the active method, the student has the opportunity of experiencing real situations and, based on them, to seek knowledge and find answers that explain the fact presented and justify actions of care. The student learns based on a the professional field of action, and as they enter the actual setting, they know how to cope and act, and do not meet the future challenges only through imagination, which makes it easier to seek solutions ${ }^{(1,24)}$.

Therefore, it is relevant to consider the integration of theory and practice in the formation of the nurse, since, in the learning process, there is a relation of reciprocity between these issues, since they are not dichotomic. Nursing care cannot be conceived as a reductive action, but as a reflective action of self-knowledge, interconnecting and articulating theory and care, which requires reflection and support from current knowledge inherent to the best practices ${ }^{(1,25-26)}$.
As a result, an emancipatory education can be achieved, which promotes autonomy and favors reflection of what is experienced in daily life, as well as social transformation. Reductionist conceptions, on the other hand, only value harmony and unit, stimulating stagnation.

The dichotomy of theory and practice makes students feel they do not have the necessary knowledge for practical actions, despite the large amount of knowledge acquired during theoretical formation. Furthermore, the teaching methods based on traditional molds do not enable them to recognize how to apply the knowledge achieved ${ }^{(1,27)}$.

There is a perceivable preparation for practical actions, which, sometimes, does not attend the needs of the health system, and can be a challenge for the educational institutions and for SUS. In this context, the DCN-Enf are important to guide the formation of a reflective professional, capable of solving complex problems and of promoting necessary change. However, most curricula are organized in a fragmented way, that is, divided per disciplines, which is a factor that complicates this change ${ }^{(28)}$.

In active learning methods, the movement to make learning concrete is the opposite. First, there is an experience, and then a theoretical contextualization, showing how the theoretical knowledge can be safely applied in professional practice ${ }^{(1,12)}$. Therefore, one expects to form critical professionals, committed to their own process of building knowledge and to safe social transformation $^{(1,26)}$. In this method, the educator has the role of observing this new context, acting from a dialogic perspective, bringing to the student the relation between that great amount of knowledge, contexts and practices, so the alumni can act in the different health determinants.

The learning, when significant, transforms the student in the subject of a process and allows for the confrontation of complex real situations. As opposed to that, teaching in the traditional modality shows a fragmented learning, organized by discipline, and its perspective is targeted at reductionism, leading to the need of conducting the formation of nursing from a different perspective ${ }^{(1,16,26)}$.

The formation focused on teamwork is to be encouraged, since it is a part of the prescriptions of SUS. However, even if this practice was encouraged in the formation of these professionals - which is what happens in this institution, in which there is integration between nursing and medicine courses and insertion in the Family Health Strategy -, it is not actualized in practice ${ }^{(1,20,25,27)}$.

Therefore, one can point at the importance of prioritizing teamwork in academic formation and practical settings, so that the different fields of knowledge can be seen as a group, aiming to understand human beings as a whole and always having in mind the idea of totality, from a perspective of integrality ${ }^{(1,15-16,26)}$. This is the only way in which the "false hope" of actualizing teamwork can be reverted.

From this perspective, Complexity Theory contributes for reflections on the current teaching and care models, proposing a transformation that can lead, through multidisciplinarity, to an understanding of the real ${ }^{(1,15-16)}$. Due to this fact, multidisciplinarity takes place in a broad, general, and dynamic context, with a holistic interpretation of facts and phenomena, through a set of situations that promotes interaction and collective action for certain ends. This is a way of being, knowing, and approaching 
that goes beyond knowledge of disciplines, since it is practiced through a dialog that considers diversity, allowing one to understand the current world. This perspective is in accordance to the needs of health work $^{(1,29)}$.

This is important so the experiences of the alumni in practice do not make them freeze, allowing them to be critically reflective about the incorporation of knowledge, of their role and of the autonomy to manage the different processes of being nurses.

It can be noticed that the alumni has an image of disorganization, because, for Complexity Theory, it is within disorganization that organization can be found. This understanding responds to the movement the alumni present towards becoming professionals, in a context in which profound changes are needed for the formation of the nurse for integral care ${ }^{(1,13,16)}$.

The importance offered to the study of specialties during graduation seems to be opposite to the generalist formation recommended by the DCN-Enf. Although generalist formation is prescribed, when the alumni face highly specialized settings, they experience feelings of missing something. Simultaneously, this absence can be fulfilled by the autonomy of the alumni in the search for the new or of the partially known ${ }^{(1,16-17,26)}$.

A study related to the formation of the nurse restated the need of finding alternatives to compartmentalize knowledge, since the disciplinary view, based on specialization, makes it more difficult to understand multidimensional problems, as they present themselves in reality ${ }^{(1,30)}$.

Starting from the understanding of this contradiction and considering that the system of health and formation of the nurse is in a clear movement towards changes, one can reiterate the statement that a changeable object, often, exists both in a given state and in a state that is not given. Therefore, for changes in teaching and caring, the contradiction must be considered ${ }^{(1,31)}$.

\section{Study limitations and contributions for the field of nursing}

A limitation of this study is the fact it was carried out in a single institution and only included alumni from three of its years. However, the findings make it possible to carry out important reflections, both in the field of formation and in the field of health, committed to the changes needed for the implementation of the SUS.

\section{FINAL CONSIDERATIONS}

In this study, the report of the alumni graduated through an integrated curriculum and according to competence, indicated that the teaching model that uses active learning methods led the students to feel secure in the job market, which they attribute to the insertion of professional practices since the first years of the course. Furthermore, they understand the encouragement to have initiative and autonomy as something essential, to learn and perform independently activities in their daily lives, which is made possible by the significant learning used in the teaching model they experienced.

Additionally, in a world in constant change, filled with uncertainty and complexity, the alumni also show difficulties, since the process of learning has been taking place in a mechanized and fragmented way, leading to difficulties in teamwork. The alumni also feel the lack of an approach focused on specialized fields, since, in the job market, they had to exercise activities in these settings ${ }^{(1)}$.

This shows contradictions in the ways the alumni act and think, which, for the complex thinking, is an inherent condition to the process in which old models coexist with new propositions, in such a way that all advances are gradual and processual ${ }^{(1)}$.

\section{REFERENCES}

1. Pinto AAM. Métodos ativos de aprendizagem ou tradicional? similaridades e diferenças entre dois cursos de enfermagem[Tese]. Botucatu: Faculdade de Medicina de Botucatu; 2018.

2. Ministério da Educação (BR). Lei no 9.394. Estabelece as diretrizes e bases da educação nacional [Internet]. Brasília; 1996 [cited 2017 Aug 13 ]. Available from: http://www.planalto.gov.br/ccivil_03/Leis/L9394.htm

3. Ministério da Educação (BR). Resolução CNE/CES n 3, de 7 de Novembro de 2001. Institui as diretrizes curriculares nacionais do curso de graduação em enfermagem [Internet]. Brasília; 2001 [cited 2017 Aug 13]. Available from: http://portal.mec.gov.br/cne/arquivos/pdf/CES03.pdf

4. Fernandes JD, Rebouças LC. A decade of National Curriculum Guidelines for Graduation in Nursing: advances and challenges. Rev Bras Enferm [Internet]. 2013 [cited 2018 Jan 10];66(esp):95-101. Available from: http://www.scielo.br/pdf/reben/v66nspe/v66nspea13.pdf

5. Souza CS, Iglesias AG, Filho AP. New approaches to traditional learning: general aspects. Medicina (Rio Preto) [Internet]. 2014 [cited 2018 Feb 22];47(3):284-292. Available from: http://revista.fmrp.usp.br/2014/vol47n3/6_Estrategias-inovadoras-para-metodos-de-ensinotradicionais-aspectos-gerais.pdf

6. Secretaria de Gestão Pública MP (BR). Competências em Educação: conceito e significado pedagógico. Guia da Gestão da Capacitação por Competências [Internet]. 2013[cited 2018 Feb 22]. Available from: http://www.gespublica.gov.br/sites/default/files/documentos/guiagestao-da-capacitacao-por-competencias_2.pdf

7. Dias IS. Competencies in Education: concept and educational meaning. Rev Assoc Bras Psicol Esc Educ [Internet]. 2010 [cited 2018 Feb 22];14(1):73-8. Available from: http://www.scielo.br/pdf/pee/v14n1/v14n1a08

8. Araujo JCS. Fundamentos da metodologia de ensino ativa (1890-1931) [Internet]. 37o Reunião Nacional da ANPED: Relatório. UFSC; 2015 [cited 03 Mar 2018]. Available from: http://37reuniao.anped.org.br/wp-content/uploads/2015/02/Trabalho-GT02-4216.pdf

9. Moraes MAA, Manzini EJ. [Conceits about Problem Based Learning: a Case Study at Famema]. Rev Bras Educ Méd [Internet]. 2006 [cited 2018 Apr 16];30(3):125-35. Available from: https://www.researchgate.net/ 
publication/240973510_Concepcoes_sobre_a_aprendizagem_baseada_em_problemas_um_estudo_de_caso_na_Famema/download Portuguese

10. Mello CCB, Alves RO, Lemos SMA. Methods of health education and training: literature review. Rev CEFAC[Internet]. 2014 [cited 2018 Jun 07];16(6):2015-28. Available from: http://www.scielo.br/pdf/rcefac/v16n6/1982-0216-rcefac-16-06-02015.pdf

11. Souza FN, Barros RN, Almeida CC, França M, Hayassy A. Comparison of traditional education and active learning methods in a subject of dental occlusion. Rev ABENO[Internet]. 2015[cited 2018 Jun 16];15(4):60-6. Available from: http://revodonto.bvsalud.org/pdf/abeno/v15n4/a09v15n4.pdf

12. Salomão D. Metodologia de ensino ativo. Rev Compart Doc [Internet]. 2016[cited 2018 Jun 07];1(1). Available from: https:// revistaseletronicas.fmu.br/index.php/CompartilheDocencia/article/view/987

13. Sobral FR, Campos CJG. The use of active methodology in nursing care and teaching in national productions: an integrative review. Rev EsC Enferm USP[Internet]. 2012[cited 2018 Jul 29];46(1):208-18. Available from: http://www.scielo.br/pdf/reeusp/v46n1/en_v46n1a28.pdf

14. Santos LML, Pelosi EM, Oliveira BCSCM. The complexity theory and the multiple approaches to understanding the social reality. Serv Soc Rev[Internet]. 2012[cited 2018 Jul 29];14(2):47-72. Available from: http://www.uel.br/revistas/uel/index.php/ssrevista/article/view/11823/11637

15. Salles VO, Mattos EASA. A Teoria da Complexidade de Edgar Morin e o ensino de ciência e tecnologia. Rev Bras Ens Cienc Tecnol. 2017;10(1):1-12. https://doi.org/10.3895/rbect.v10n1.5687

16. Silva BFL. A Teoria da Complexidade e o seu princípio educativo: as ideias educacionais de Edgar Morin. Polyphonía. 2011;22(2). https://doi. org/10.5216/rp.v22i2.26682

17. Morin E. Introdução ao pensamento complexo. 2a ed. Lisboa: Instituto Piaget; 1990.

18. Silva LS, Camillo SO. A educação em enfermagem à luz do paradigma da complexidade. Rev Esc Enferm USP. 2007;41(3):403-10. https://doi. org/10.1590/S0080-62342007000300009

19. Chirelli MQ, (Coord.). Currículo do Curso de Enfermagem - FAMEMA. Marília: Faculdade de Medicina de Marília;1997.

20. Antunes C. Novas maneiras de ensinar, novas formas de aprender. Porto Alegre: Artmed;2002.

21. Faculdade de Medicina de Marília. Projeto Pedagógico do Curso de Enfermagem. Faculdade de Medicina de Marília. Marília; 2008.

22. Cardoso MF, Santos ACB, Alloufa JML. Subject, language, ideology and world: hermeneutic-dialectic as a research technique for qualitative data analysis in critical management studies. Rev Adm FACES J [Internet]. 2015[cited 2018 Jul 29];14(2):74-93. Available from: http://www. fumec.br/revistas/facesp/article/view/2112/1679

23. Alencar TOS, Nascimento MAA, Alencar BR. Dialectical hermeneutics: an experience as a method of analysis in research on the user access to pharmaceutical services. Rev Bras Promoç Saúde [Internet]. 2015[cited 2018 Aug 12];25(2):243-250. Available from: http://periodicos.unifor. br/RBPS/article/view/2236/2460

24. Gadamer HG. Verdade e método: traços fundamentais de uma hermenêutica filosófica. 15a ed. Editora Vozes; 1999.

25. Rodrigues CCFM, Carvalho DPSRP, Salvador PTCO, Medeiros SM, Menezes RMP. Marcos Ferreira Jr A, et al. Ensino inovador de enfermagem a partir da perspectiva das epistemologias do sul. Esc Anna Nery. 2016;20(2):384-9. https://doi.org/10.5935/1414-8145.20160053

26. Nascimento ES, Santos GF, Caldeira VP, Teixeira VMN. Formação por competências do enfermeiro: alternância teoria-prática, profissionalização e pensamento complexo. Rev Bras Enferm. 2003;56(4):447-52. https://doi.org/10.1590/S0034-71672003000400030

27. Cruz RAO, Araújo ELM, Nascimento NM, Lima RJ, França JRFS, Oliviera JS. Reflections in the light of the complexity theory and nursing education. Rev Bras Enferm [Internet]. 2017[cited 2018 Aug 12];70(1):236-9. Available from: http://www.scielo.br/pdf/reben/v70n1/en_0034-7167reben-70-01-0236.pdf

28. Cunha CMSLM, Macedo APMC, Vieira IFGFF. Percepções dos estudantes de enfermagem sobre os processos formativos em contexto de ensaio clínico. Rev Enferm Ref. 2017;4(12):65-74. https://doi.org/10.12707/RIV16072

29. Magnano C, Pierantoni CR. A formação de enfermeiros e sua aproximação com os pressupostos das Diretrizes Curriculares Nacionais e da Atenção Básica. Ciênc Saúde Colet. 2020;25(1). https://doi.org/10.1590/1413-81232020251.28372019

30. Farias MF, Sonalgio KE. Perspectivas multi, pluri, inter e transdisciplinar no turismo. Rev lberoam Tur [Internet]. 2013 [cited 2018 Aug 12];3(1):71-85. Available from: https://www.seer.ufal.br/index.php/ritur/article/view/806

31. Peres RR, Camponogara S, Costa VZ, Terra MG, Niestche EA. Saúde e ambiente: (in) visibilidades e (des) continuidades na formação profissional em enfermagem. Esc Anna Nery. 2016;20(1):25-32. https://doi.org/10.5935/1414-8145.20160004

32. Marquit E. Contradição na dialética e na lógica formal. Princípios Rev Teór Polít Inf [Internet]. 1996 [cited 2017 Oct 21];43:58-68. Available from: http://www.grabois.org.br/cdm/colecao-principios/151718-44623/1996-11-01/contradicoes-na-dialetica-e-na-logica-formal 